\title{
PROTECTIVE ACTIONS OF GHRELIN ON GLOBAL CEREBRAL ISCHEMIA- INDUCED MEMORY DEFICITS
}

\begin{abstract}
Received 25.11.2013
In our study, we investigated transient global cerebral ischemia (TGCI) -induced changes of spatial memory and motor activity together with apoptotic, oxidant, and NO/NOS signaling parameters in rats and the effects of treatment of the animals with ghrelin. The TGCI-induced deficiencies of spatial memory and motor activity in the Y-maze and open field tests were attenuated by ghrelin treatment. Furthermore, ghrelin administration lowered the levels of caspase- 3 and iNOS elevated by TGCI in the hippocampus. Thus, we conclude that ghrelin exerts the neuroprotective action against hippocampal TGCI injury via influencing apoptotic, oxidant, and/or NO/NOS pathways. If underlying mechanisms of the action of this agent will be fully clarified, ghrelin might be a candidate drug for treatment of TGCI-induced memory impairments.
\end{abstract}

KEYWORDS: transient global cerebral ischemia, ghrelin, hippocampus, caspase-3, total oxidant status, nitric oxide.

\section{INTRODUCTION}

Transient global cerebral ischemia (TGCI), usually stemming from a severe arrhythmia, cardiac arrest, or hemorrhagic shock, is a leading cause of death and adult disability in industrialized countries, and the respective treatment options are limited [1]. Even though several agents have been found to be neuroprotective in animal models, most of them have failed to be transferred from the laboratory to the clinics [2]. Thus, there is a huge medical need to develop novel therapies for TGCI.

Neurophysiological dysfunctions, including learning and memory disabilities, are major outcomes of TGCI, mediated through delayed neuronal death (DND) starting 2-3 days after reperfusion mostly in the cerebral cortex and hippocampus [1]. The latter is the brain structure greatly vulnerable to neurodegenerative effects of TGCI in humans [35] and animals [6]. Hence, behavioral and cognitive disturbances, particularly within the learning and memory domains, are the most apparent symptoms of TGCI, and loss of spatial learning and memory

\footnotetext{
${ }^{1}$ Medical School of the Akdeniz University, Antalya, Turkey.

${ }^{2}$ Medical School of the Near East University, North Nicosia, Northern Cyprus. Correspondence should be addressed to N. Derin

(e-mail: nderin07@gmail.com or narinderin@akdeniz.edu.tr).
}

abilities are the parameters usually described in rodent models of TGCI [7].

Delayed neuronal death is suggested to involve apoptosis, the programmed cell death essential for eliminating damaged or aged cells and maintaining tissue integrity [8]. The specific morphological changes associated with apoptosis are cell shrinkage, chromatin condensation, internucleosomal deoxyribonucleic acid (DNA) fragmentation, and formation of apoptotic bodies [9]. The majority of morphological and biochemical changes stem from various enzymatic reactions most of which are catalyzed by caspases playing essential roles during apoptotic cell death [10]. There are two types of caspases: initiator caspases (caspases 8, 10, 9, and 2) and effector caspases (caspases 3, 7, and 6); the latter are activated by initiator ones [11]. Among all members of the caspase family, caspase- 3 is the most abundant in the brain, and its activation is considerably implicated in ischemic cell death [12].

Oxidative stress, stemming from distortion of the equilibrium between production and scavenging of free radicals, is one of the most important pathological mechanisms leading to DND following TGCI [13]. Beside oxidative stress, nitrosative stress is another pathological mechanism significantly contributing to DND induced by excessive nitric oxide (NO) production through nitric oxide synthases (NOSs) 
enzymes [14]. The role of NO in pathogenesis of ischemic brain damage is controversial. Some evidence has been accumulated that NO plays both neurotoxic and neuroprotective roles during the process of cerebral ischemia and reperfusion $[15,16]$. Moreover, modulation of different NOSs, such as neuronal NOS (nNOS), inducible NOS (iNOS), and endothelial NOS (eNOS), have been shown to produce a variety of outcomes in ischemic brain injury [17]. Neuronal NOS and especially iNOS activities have been proposed to be detrimental to the ischemic brain [18-20]. Hence, agents preventing iNOS overexpression, such as ghrelin, might be potential therapeutic means in TGCI [21].

Ghrelin is a 28 -amino acid peptide esterified with octanoic acid on serine 3 . It is mainly released from oxyntic cells of the stomach mucosa. The ability of ghrelin to stimulate growth hormone $(\mathrm{GH})$ release by activating GH secretagogue receptors (GHSRs 1a) in the pituitary was discovered [22]. Ghrelin has several other peripheral actions, including direct effects on the systemic vascular resistance, gastric secretion, stomach motility, sleep, learning, and memory [23-27]. Additionally, recent studies highlighted that ghrelin also exerts neuroprotective actions in ischemic models of stroke both in vivo and in vitro $[28,29]$.

Therefore, our study was conducted to search the effects of ghrelin on TGCI-induced hippocampal damage and memory impairments together with its relation to apoptotic, oxidant, and NO/NOS signaling in rats.

\section{METHODS}

Animals. Forty-five adult male Wistar rats weighing 300-350 g were used for the experiments. The animals were housed at room temperature $\left(23 \pm 1{ }^{\circ} \mathrm{C}\right)$ and 12 -h day/night cycle and supplied with standard laboratory chow and water ad libitum.

Experimental Procedures. Rats were randomly divided into control (C), ischemia/reperfusion (IR) and ischemia/reperfusion + ghrelin $(\mathrm{IR}+\mathrm{G})$ groups $(n$ $=15$ in each group). Rats of the $\mathrm{C}$ group underwent sham surgery, i.e., without vessel occlusion, and received saline via intraperitoneal (i.p.) daily injections of vehicle after reperfusion for three days. The IR-group rats were exposed to global cerebral ischemia/reperfusion and received daily saline via i.p. injections of vehicle also for three days of reperfusion. Rats of the IR $+\mathrm{G}$ group, underwent global cerebral ischemia/reperfusion surgery and received daily ghrelin injections $(80 \mu \mathrm{g} / \mathrm{kg} \cdot$ day, i.p. $)$ as treatment for three post-reperfusion days [28]. The Y-maze and open field tests were carried out on the first and second post-reperfusion days. The Y-maze test was followed by the open field test with a 1-h-long time interval. On the third day after reperfusion, rats were perfused transcardially with heparinized saline under deep urethane anesthesia; the brains were removed immediately, and the extracted hippocampi were stored at $-80^{\circ} \mathrm{C}$ for biochemical assays.

Drug Preparation. Rat ghrelin, purchased from GenScript Inc. (USA) was dissolved in distilled water $(1 \mathrm{mg} / \mathrm{ml})$, and stored at $-20^{\circ} \mathrm{C}$ until the time of preparation for administration. Immediately before administration by i.p. injection, ghrelin was diluted again with $0.9 \%$ saline to the final concentration of $0.1 \mathrm{mg} / \mathrm{ml}$. [30].

Global Cerebral Ischemia/Reperfusion. Global ischemia was induced by four-vessel occlusion (4-VO), as previously described by Pulsinelli and Brierley [31], with a modification. In brief [32], an incision was made $2.5 \mathrm{~cm}$ dorsal to the cervical midline under deep ketamine/xylazine anesthesia $(100 / 10 \mathrm{mg} / \mathrm{kg}$, i.p.), and vertebral arteries were irreversibly occluded by electrocoagulation through the alar foraminae of the 1 st cervical vertebra. Immediately after electrocoagulation, bitemporal subdermal EEG needle electrodes were placed in reference to a frontal subdermal electrode, and an incision was made $2.5 \mathrm{~cm}$ with respect to the ventral cervical midline. After a baseline EEG level had been estimated, both common carotid arteries were exposed and occluded with micro aneurysm clips for $8 \mathrm{~min}$, and this was followed by reperfusion. The experiments were performed only if the animals showed a completely flat bitemporal EEG during the carotid artery occlusion. Sham-operated rats underwent all procedures except the latter bilateral common carotid artery occlusion. A heating pad was applied in order to maintain the rats' body temperature at $37 \pm 0.5^{\circ} \mathrm{C}$. Each group of animals received the same degree of surgical manipulations and the same recovery paradigms, to minimize variations that could be induced by surgical procedures.

\section{Behavioral Tests}

The Y-maze Test. Spatial memory was evaluated using a Y-maze test paradigm [33] at 24 and $48 \mathrm{~h}$ after ischemia. The maze was constructed of grey Plexiglas and consisted a stem arm (42 cm long) and two identical arms (37 cm long, diverging at a $45^{\circ}$ angle 
from the stem arm) surrounded by extra-maze cues of varying shapes and sizes. During 15-min information trial, rats were free to explore the stem arm and one of the second arms, but access to the third arm (novel arm) was blocked by a plastic partition. Following the initial information trial, rats were returned to their home cages for a 4-h-long interval. After the delay, each rat re-entered the Y-maze in the stem arm and was allowed to explore all three arms during a 5-min retention trial. Retention trials were video-recorded (Noldus Ethovision XT System, country?) for scoring the arm entries. Arm entry was defined as all four paws crossed the dividing line between the arm and the central area. The maze was cleaned thoroughly with $70 \%$ ethanol and air-dried after each trial to remove olfactory cues. Spatial memory was indicated by increased entries into the novel arm during the retention trial.

Open Field. Exploratory behavior was tested in an open field constructed of black Plexiglas $(100 \mathrm{~cm} \times 100 \mathrm{~cm} \times 45 \mathrm{~cm})$ arena. Each rat was placed in the center of the open field and allowed a single exploration trial of $3 \mathrm{~min}$. The floor and walls were cleaned thoroughly with $70 \%$ ethanol and allowed to air-dry after each trial, to remove olfactory cues. The activity was monitored by a video camera and recorded to allow for later analysis. The field was virtually divided into 16 equal-sized squares. Entry into a square was scored when the rat crossed the borders of a designated square with all four paws. Exploratory behavior and locomotor activity were evaluated by calculating the total number of squares entered and total distance moved, respectively [33].

\section{Biochemical Assays}

Estimation of the Total Oxidant Status (TOS). Total oxidant status was measured by a commercially available TOS assay kit (cat. No. RL0024, Rel Assay Diagnostics, Turkey). The assay was calibrated with hydrogen peroxide, and the results are expressed below as $\mu \mathrm{M} \mathrm{H}_{2} \mathrm{O}_{2}$ /g protein.

NO Metabolites (Nitrite+Nitrate). The nitrite+nitrate level was measured using a commercial nitrate/nitrite colorimetric assay kit (cat. No. 78001; Cayman Chemical, USA) in accordance with the manufacturer's instructions. Briefly, the hippocampi were dissected on ice, homogenized in PBS, and centrifuged at $10,000 \mathrm{~g}$ for $20 \mathrm{~min}$. The supernatant was centrifuged at $100,000 \mathrm{~g}$ for $30 \mathrm{~min}$ and then filtered through a $10-\mathrm{kDa}$ molecular mass cutoff filter. The nitrate+nitrite level was measured in duplicate on 96-well plastic microplates. The absorbance was read at 570/620 nm using a multiwell microplate reader.

Immunohistochemistry of iNOS, nNOS, and Caspase-3. Under deep anesthesia, animals were perfused transcardially with $200 \mathrm{ml}$ of saline followed by $300 \mathrm{ml}$ of $4 \%$ paraformaldehyde solution. Brains were removed and postfixed in the same paraformaldehyde solution for $24 \mathrm{~h}$ and then embedded in paraffin. Five$\mu \mathrm{m}$-thick coronal sections were cut, collected on polyL-lysine coated slides (Sigma-Aldrich, USA) and incubated overnight at $56^{\circ} \mathrm{C}$. For immunohistochemical assays, brain sections were deparaffinized in xylene and rehydrated in a graded ethanol series. Sections were then treated with $10 \mathrm{mM}$ citrate buffer $(\mathrm{pH}$ 6.0) for 5 min twice in a microwave oven and left to cool down for $20 \mathrm{~min}$. After three washes in phosphate-buffered saline (PBS), sections were incubated in a universal blocking reagent (BioGenex, USA) for $7 \mathrm{~min}$ at room temperature in order to block nonspecific binding. Subsequently, sections were incubated overnight at $4{ }^{\circ} \mathrm{C}$ with rabbit anti-iNOS (1:200; ab3523), rabbit anti-nNOS (1:100; ab76067, both from Abcam, USA) and cleaved caspase-3 (1:100, Cell Signaling No. 9661) primary antibodies. After several washes in PBS, sections were incubated with goat anti-rabbitbiotin secondary antibody (1:400; Vector Labs, USA) for $60 \mathrm{~min}$ at room temperature and rinsed with PBS. Visualization was performed via a streptavidinperoxidase complex (Dako, USA) and diaminobenzidine (BioGenex). Sections were counterstained with Mayer's hematoxylin (Dako), mounted with Kaisers GlycerolGelatin (Merck Kaisers Glycerin Gelatine, Cat No: 1.09242.0100, , Germany), and were examined using a light microscope.

Statistical Analysis. The obtained numerical data were treated by SPSS (version 18.0) software package for Windows. Since the numbers of entries to the novel arm in the Y-maze did not follow a normal distribution, and their variance did not fit the assumption of homoscedasticity, the relevant data are expressed as medians (min-max), while the remaining results are expressed as means \pm s.e.m. All variables were analyzed with the non-parametric Kruskal-Wallis test, and all pairwise multiple comparisons were performed by the Mann-Whitney U test; differences with $P$ values smaller than 0.05 were considered significant.

\section{RESULTS}

TGCI-Induced Spatial Memory Changes and Effects of Ghrelin Treatment. Table 1 shows number 
T a b l e 1. Indices observed in the Y-maze test.

Т а б л и ц 1. Результати тестування у Ү-подібному лабіринті.

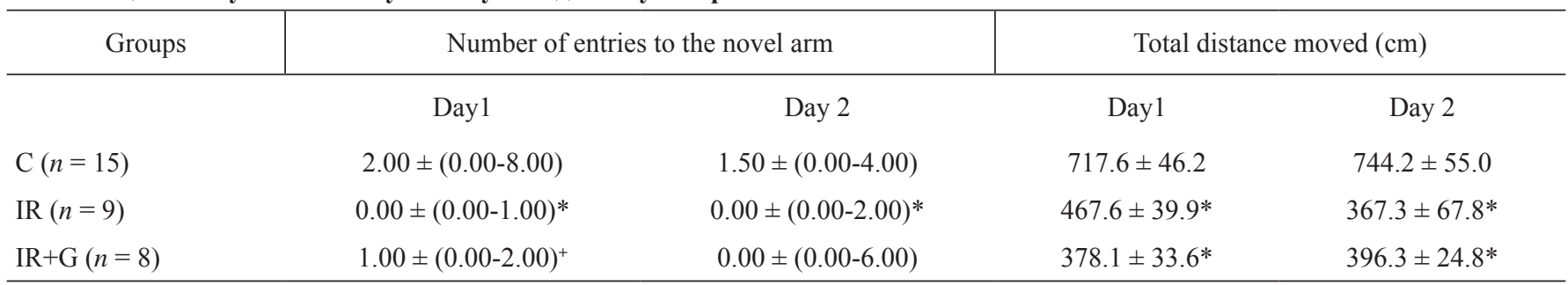

Footnotes. Numbers of entries to the novel arm are expressed as medians \pm (min-max), while other results are expressed as means \pm s.e.m. ${ }^{*} P<0.05$ compared to the $\mathrm{C}$ group, ${ }^{+} \mathrm{P}<0.05$ compared to the IR group.

T a b l e 2. Indices observed in the open field test.

Т а б л и ц я 2. Результати тестування у відкритому полі.

\begin{tabular}{lcccc}
\hline \multicolumn{1}{c}{ Groups } & \multicolumn{2}{c|}{ Number of squares entered } & \multicolumn{2}{c}{ Total distance moved (cm) } \\
\hline & Day 1 & Day 2 & Day1 & Day 2 \\
$\mathrm{C}(n=15)$ & $28.79 \pm 4.01$ & $27.67 \pm 3.73$ & $679.8 \pm 90.2$ & $691.8 \pm 101.0$ \\
$\mathrm{IR}(n=9)$ & $8.67 \pm 1.04^{*}$ & $8.83 \pm 1.56^{*}$ & $386.2 \pm 38.6^{*}$ & $436.5 \pm 63.3^{*}$ \\
$\mathrm{IR}+\mathrm{G}(n=8)$ & $19.00 \pm 4.16^{+}$ & $22.33 \pm 4.04^{+}$ & $515.9 \pm 75.6^{+}$ & $612.1 \pm 74.1^{+}$ \\
\hline
\end{tabular}

Footnotes. Means \pm s.e.m are shown, ${ }^{*} P<0.05$ compared to the $\mathrm{C}$ group, ${ }^{+} P<0.05$ compared to the IR group.

of entries to the novel arm and total distance moved in the Y-maze. The number of entries to the novel arm and total distance moved were smaller in the IR group with respect to the $\mathrm{C}$ group on both post-reperfusion day 1 and day 2 . On day 1 , ghrelin administration resulted in an increase of the number of entries to the novel arm, as compared to the IR group; however, on

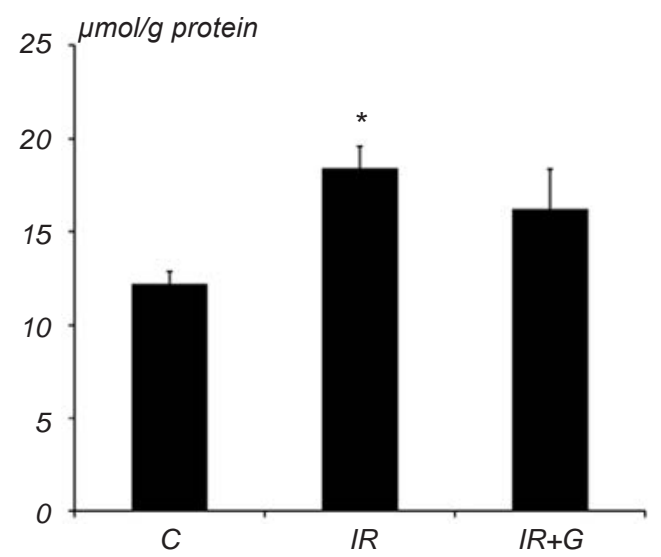

F i g. 1. Total oxidant status ( $\mu \mathrm{mol} \mathrm{H}_{2} \mathrm{O}_{2} / \mathrm{g}$ protein) in the hippocampi of rats of the $\mathrm{C}(n=12)$, IR $(n=6)$, and $\mathrm{IR}+\mathrm{G}(n=5)$ groups. Means \pm s.e.m. are shown; $*$ indicates a significant difference $(P<0.05)$ with respect to group $\mathrm{C}$.

$\mathbf{P}$ и с. 1. Загальний оксидантний статус (мкмоль $\mathrm{H}_{2} \mathrm{O}_{2} / \Gamma$ протеїну) в гіпокампах щурів груп контролю $(\mathrm{C}, n=12)$, ішеміїреперфузії (IR, $n=6)$ та ішемії-реперфузії+грелін $(\mathrm{IR}+\mathrm{G}, n=5)$. day 2 no significant effect of the drug was observed. Ghrelin treatment did not cause significant changes in the total distance moved in the IR $+\mathrm{G}$ group neither on day 1 nor on day 2 .

TGCI-Induced Motor Activity Changes and Effects of Ghrelin Treatment. The number of squares entered and total distance moved in the open field test

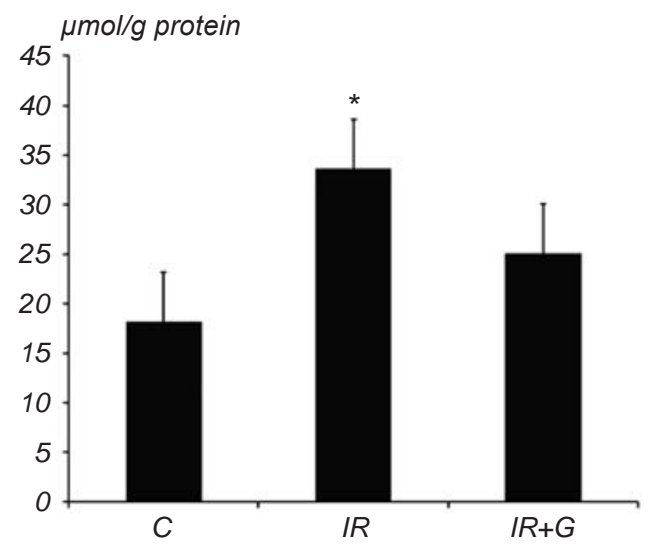

F i g. 2. Nitrite + nitrate levels ( $\mu \mathrm{mol} / \mathrm{g}$ protein) in the hippocampi of the $\mathrm{C}, \mathrm{IR}$, and $\mathrm{IR}+\mathrm{G}$ groups. Designations are similar to those in Fig. 1.

Р и с. 2. Рівні нітритів+нітратів (мкмоль/г протеїну) в гіпокампах щурів груп C, IR тa IR+G. 

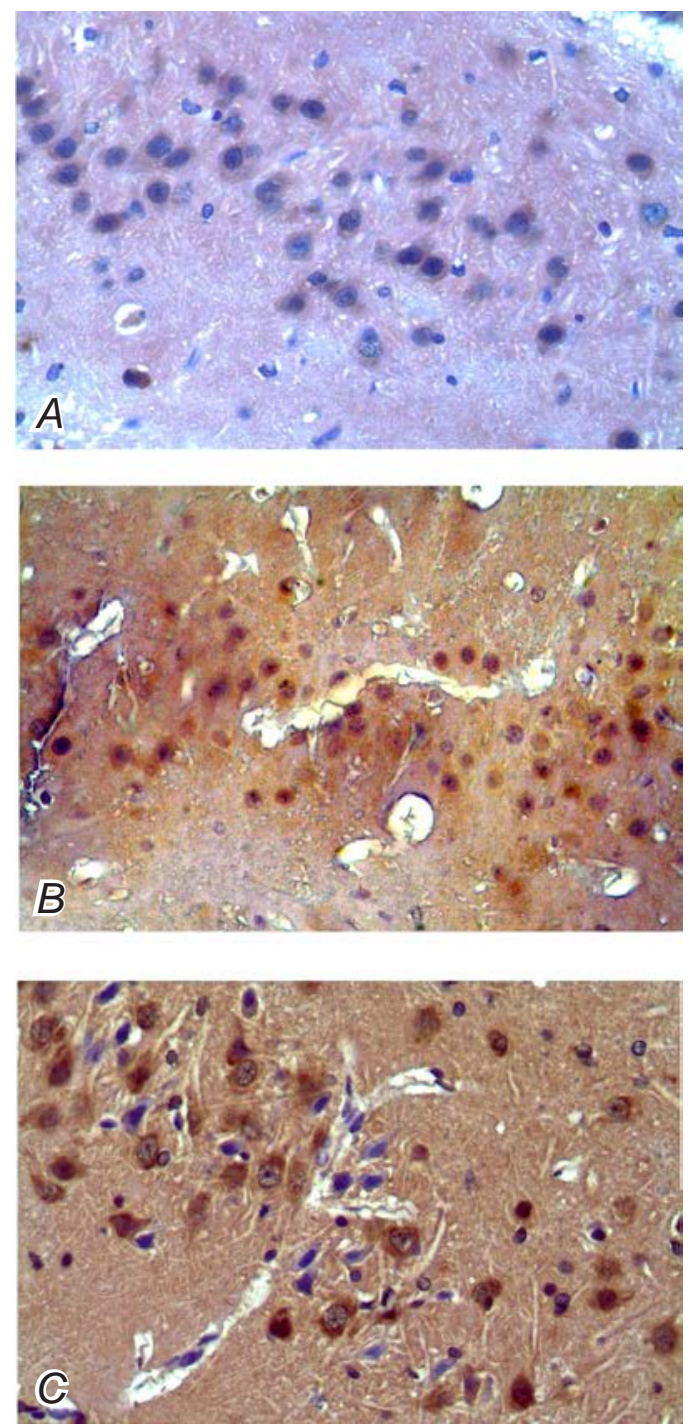

F i g. 3. iNOS expression in hippocampal slices of rats of the C, IR, and $\mathrm{IR}+\mathrm{G}$ groups (A-C, respectively); 40x.

P и с. 3. Експресія iNOS у зрізах гіпокампа щурів груп C, IR та IR+G (А-С відповідно).

for all experimental groups are shown in Table 2. Both these indices were significantly lower in the IR group compared to the $\mathrm{C}$ group on both day 1 and day 2 . Ghrelin administration significantly increased both the number of squares entered and the total distance moved on day 1 and day 2 in the $I R+G$ group with respect to the IR group.

Hippocampal TOS Levels. Total oxidant status results are illustrated by Fig. 1. The respective index was significantly greater in the IR group $(18.41 \pm 1.14 \mu \mathrm{M}$ $\mathrm{H}_{2} \mathrm{O}_{2} / \mathrm{g}$ protein) in reference to the $\mathrm{C}$ group (12.19 \pm
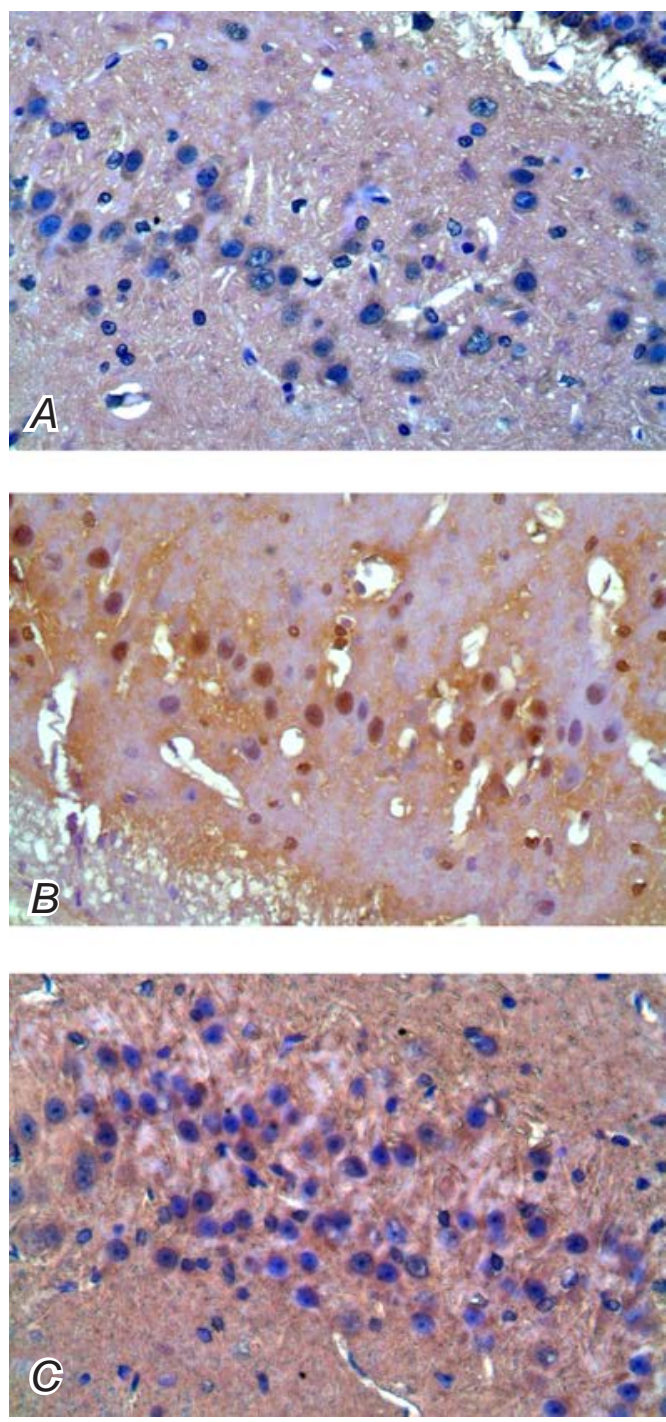

F i g. 4. nNOS expression in hippocampal slices of rats of the C, IR, and $\mathrm{IR}+\mathrm{G}$ groups (A-C, respectively); 40x.

P и с. 4. Експресія $\mathrm{nNOS}$ у зрізах гіпокампа щурів груп C, IR та $\mathrm{IR}+\mathrm{G}$ (А-С відповідно).

$\pm 0.67 \mu \mathrm{M} \mathrm{H}_{2} \mathrm{O}_{2} / \mathrm{g}$ protein). Ghrelin treatment lowered the TOS level in the IR $+\mathrm{G}$ group $(16.19 \pm 2.16 \mu \mathrm{M}$ $\mathrm{H}_{2} \mathrm{O}_{2}$ /g protein) with respect to the IR group; however, this effect was not statistically significant.

Hippocampal Nitrite+Nitrate Levels. Nitrite and nitrate levels in the hippocampus are shown in Fig. 2. These levels were higher in both the IR $(33.61 \pm$ $\pm 4.59 \mu \mathrm{M} / \mathrm{g}$ protein $)$ and $\mathrm{IR}+\mathrm{G}$ groups $(25.05 \pm 3.16$ $\mu \mathrm{M} / \mathrm{g}$ protein) than in $\mathrm{C}$ group $(18.17 \pm 0.92 \mu \mathrm{M} / \mathrm{g}$ protein). Although a decrease in the hippocampal nitrite+nitrate levels was observed in the $\mathrm{IR}+\mathrm{G}$ group 

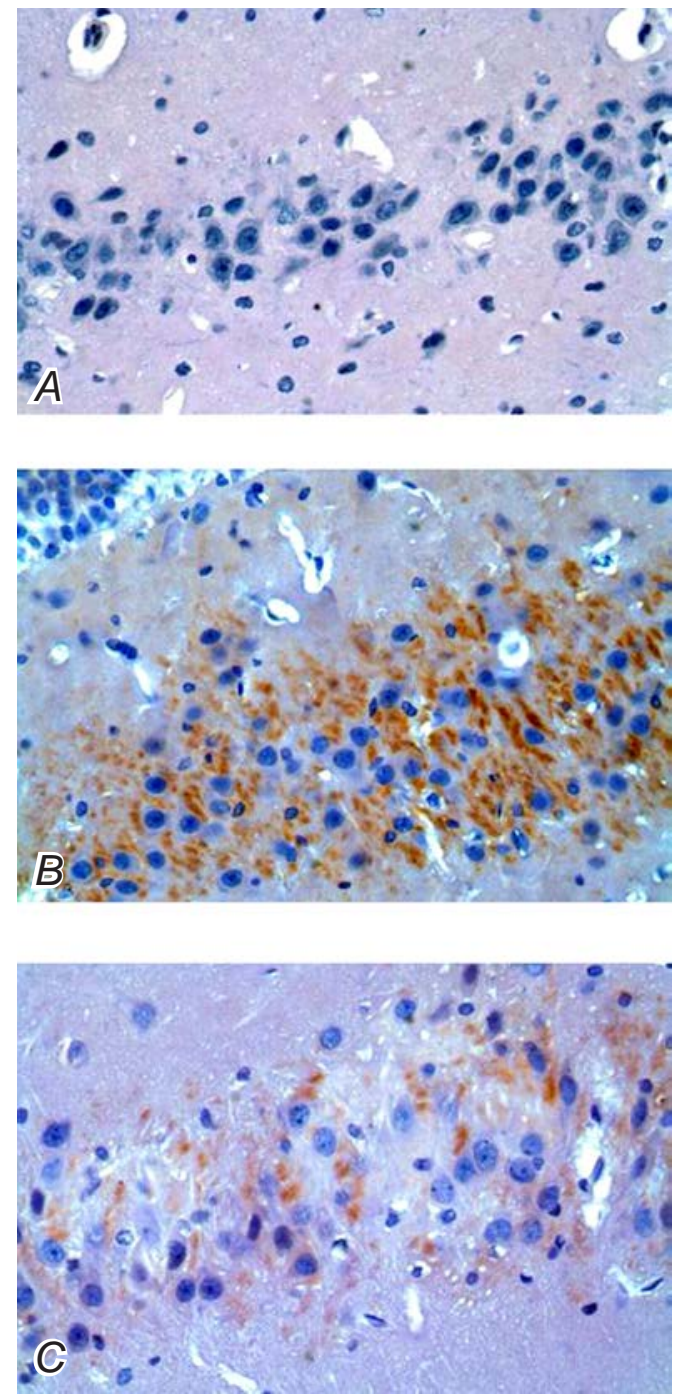

F i g. 5. Caspase-3 expression in hippocampal slices of rats of the $\mathrm{C}$, IR, and IR $+\mathrm{G}$ groups (A-C, respectively); 40x.

P и с. 5. Експресія каспази-3 у зрізах гіпокампа щурів груп $\mathrm{C}$, IR та IR+G (А-С відповідно).

compared to the IR group, the difference did not rich the level of significance.

Hippocampal iNOS Expression. Hippocampal iNOS immunoreactivity (brown straining) was evaluated by immunohistochemistry (Fig. 3). The immunoreactivity with respect to iNOS in the hippocampus was significantly higher in the IR group (Fig. 3B) with respect to the $\mathrm{C}$ group (Fig. 3A). Ghrelin treatment noticeably decreased the number of iNOS-positive neurons in the IR $+\mathrm{G}$ group (Fig. $3 \mathrm{C}$ ) in reference to the IR group.

Hippocampal nNOS expression. Hippocampal
nNOS immunoreactivity (brown staining) was also evaluated by immunohistochemistry (Fig. 4). The nNOS immunostaining was mostly observed in the hippocampi in the IR group (Fig. 4B). There was weak nNOS immunolabelling found in the $I R+G$ group (Fig. 4C). No significant difference was observed between the nNOS immunoreactivity in the $\mathrm{C}$ and $\mathrm{IR}+\mathrm{G}$ groups.

Hippocampal Cleaved Caspase-3 Expression. Immunohistochemical analysis of the hippocampal region demonstrated that the caspase-3 level was elevated after TGCI in the IR group (Fig. 5B). Ghrelin caused a strong decrease in the caspase-3 level in the IR $+\mathrm{G}$ group (Fig. 5C) compared to the abovementioned IR group. No caspase-3 expression was observed in the $\mathrm{C}$ group (Fig. 5A).

\section{DISCUSSION}

Even though TGCI is one of the leading causes of human death and disability across the world [34], there are still very limited therapeutic options [35]. Hence, this dramatic disorder remains a demanding clinical problem for which the development of new therapies is necessary.

Patients who experienced TGCI usually suffer from various degrees of memory impairment and learning dysfunction due, to a significant extent, to the hippocampal damage $[36,37]$. Circulating ghrelin in the hippocampus was shown to cross the bloodbrain barrier, to enhance long-term potentiation (LTP), and to improve spatial memory [38]. Based on these results, we investigated the possible therapeutic effects of ghrelin on TGCI-induced deterioration of spatial memory and exploratory behavior in rats. Our data suggested that ghrelin has a clear positive effect on spatial memory impairment induced by TGCI on the first day after reperfusion. However, its protective effect mostly vanished on the second postreperfusion day. This situation might occur due to an insufficient dose of ghrelin used in our experiments. In other words, as hippocampus-dependent memory impairment progresses within the reperfusion period, an administered amount of ghrelin could not be adequate to overcome the damage within later segments of the post-reperfusion period. In addition, ghrelin administration resulted in enhancement of motor activity that was previously deteriorated by TGCI. The alleviative effect of ghrelin on motor activity was observed not only on the first day, but 
also on the second day after reperfusion. Although memory- and motor activity-enhancing effects of ghrelin were reported in the literature, the underlying mechanism has not been fully understood yet [39]. Therefore, further studies are required to clarify the mechanisms of action of this agent.

The hippocampus is selectively vulnerable to TGCI; hippocampal degeneration begins to be observed histologically 2-3 days after ischemia [6]. In reference to these crucial findings, we evaluated apoptotic changes in the hippocampus three days after ischemia via caspase-3 immunostaining, in order to see is there any correlation between behavioral and apoptotic changes. Ultimately, higher caspase-3 immunoreactivity was observed in the IR group with respect to the $\mathrm{C}$ group. In the same line with our findings, Liu et al. [40] showed that 8-min-long TGCI resulted in dramatic cell loss in the hippocampus three days after ischemia. Pooling our behavioral and histological results together, we can suggest that TGCI causes memory impairment by inducing DND via an apoptotic pathway in the hippocampus.

At present, a few investigations are being carried out in order to suggest neuroprotective therapies to overcome hippocampal degeneration caused by TGCI. Recent studies highlighted neuroprotective actions of ghrelin in ischemic models of stroke, both in vivo and in vitro. In vivo rat IR models showed that ghrelin provides significant neuroprotection in the forebrain by reducing an infarct volume and cell death [28, 29]. We also observed that ghrelin treatment $(80 \mu \mathrm{g} / \mathrm{kg})$ lowered the caspase- 3 immunoreactivity in the IR $+G$ group. Together with behavioral changes, it might be suggested that ghrelin attenuates TGCI-induced memory impairment by affecting an apoptotic pathway. In that respect, ghrelin might be considered as a potential therapeutic mean with respect to hippocampal TGCI injury. Therefore, further researches should be conducted in order to find out the details of molecular pathway mediating the anti-apoptotic action of ghrelin.

Oxidative stress, the consequence of free radical overproduction, is a well-identified pathophysiological mechanism of IR injury [41, 42]. With the beginning of reperfusion, abrupt oxygenation of the brain tissue causes excessive production of oxygen radicals intensely oxidizing membrane lipids, cellular proteins, and DNA, thus leading to intensification of apoptosis [43]. In our study, similar to previous reports, we also observed an elevation of TOS in the hippocampus after TGCI. We, however, found that ghrelin administration did not significantly lower the
TOS level in the IR $+\mathrm{G}$ group. At the same time, other authors [44, 45] suggested that ghrelin expression affects oxidative stress in different cell types. Our negative result might be related to a dose of ghrelin insufficient to reduce oxidative stress significantly. In order to clarify the pathways mediating possible effects of ghrelin, protein levels, mRNA expression, and activities of both oxidant and antioxidant enzymes should be investigated in a dose-dependent manner in further studies.

Nitric oxide, a highly reactive signaling molecule in the CNS is one of the free radicals elevated during ischemic brain injury [46]. Being a gaseous chemical messenger, NO plays key roles in neuronto-neuron communication, synaptic plasticity, and memory formation [47, 48]. Unless existing in physiological low concentrations, NO might affect the tissues through toxic actions mediated mostly by the peroxinitrite radical (ONOO-) [49]. Although not being fully understood yet, the mechanism underlying TGCI injury is suggested to involve NO signaling due to the induction of excessive NO production $[50,51]$. Together with NO, the levels of its metabolites, such as nitrites and nitrates, are also elevated following TGCI [52]. In our study, a marker of NO production, the nitrite+nitrate level, was elevated in the hippocampus after TGCI. We observed that ghrelin administration lowered this level in the hippocampi in the $I R+G$ group, but the effect was not statistically significant. Alterations in the nitrite+nitrate concentration might be explained by changes in the hippocampal NOS levels.

Nitric oxide is a "double-edged sword" in IR injury; in addition to the amount, the source of NO is another crucial factor dominating its effects in cerebral ischemia. Nitric oxide produced by eNOS has been suggested to exert beneficial effects during cerebral ischemia-reperfusion; nNOS and, especially, iNOS are considered to be detrimental since they produce a considerable amount of NO resulting in DNA damage [53]. We found that iNOS and nNOS immunoreactivities were raised in the hippocampus after TGCI. Therefore, the high nitrite+nitrate level in the IR group can be attributed to increases in the iNOS and nNOS levels. The latter effect (increase of iNOS and nNOS expressions) was reported by other authors in focal cerebral ischemia models in mice and rats [54-56]. Ghrelin treatment, on the other hand, lowered iNOS and nNOS immunoreactivities in the $\mathrm{IR}+\mathrm{G}$ group, as compared with the IR group. Hence, we can conclude that the lower nitrite+nitrate level 
was a consequence of decreases in iNOS and nNOS expressions in the $\mathrm{IR}+\mathrm{G}$ group with respect to the IR group. Indeed, ghrelin has in several reports been suggested to modulate NO/NOS signaling [57, 58]. Brzozowski et al. [58] showed that ghrelin inhibits expression of iNOS mRNA under stress conditions and upregulates constitutive NOS (eNOS and nNOS) mRNA. Additionally, Carlini et al. [57] suggested that ghrelin affects memory consolidation and reduces the LTP threshold through the NO/NOS signaling pathway. Similarly to previous studies, the observed effect of ghrelin on TGCI-induced memory changes in our study might also to a noticeable extent be attributed to NO/NOS pathway modulation.

Thus, we examined the effects of ghrelin on TGCIinduced behavioral impairment and accompanying changes in the apoptotic, oxidant, and NO/NOS pathways in the rat hippocampus. Pooling all results together, ghrelin might be a candidate drug for treatment of TGCI-induced memory impairment provided that the underlying mechanisms should be fully clarified in further studies.

Acknowledgements. This work was supported by a grant from the Research Foundation of the Akdeniz University, Turkey (project No. 2009.02.0122.017). This study was carried out as a part of the MSc thesis by G. Başaranlar presented to the Akdeniz University Health Sciences Institute.

All experimental procedures were carried out in agreement with the internationally accepted regulations and approved by the Animal Care and Use Committee of the Akdeniz University.

The authors, G. Basaranlar, N. Derin, R. Tan, G. Tanriover, and N. Demir, have no conflict of interests.

\section{Г. Базаранлар ${ }^{1}$, Н. Дерін ${ }^{1}$ Р. Тан ${ }^{2}$, Г. Танріовер ${ }^{1}$, Н. Демір ${ }^{1}$ \\ ПРОТЕКТИВНИЙ ВПЛИВ ГРЕЛІНУ НА РОЗЛА- \\ ДИ ПАМ'ЯТІ У ЩУРІВ, ЗУМОВЛЕНІ ГЛОБАЛЬНОЮ ЦЕРЕБРАЛЬНОЮ ІШЕМІЄЮ}

\author{
${ }^{1}$ Університет Акденіз, Анталія (Туреччина). \\ ${ }^{2}$ Близькосхідний Університет, Північна Нікозія (Північний \\ Кіпр). \\ P е 3 ю м е
}

У наших дослідах ми вивчали зміни просторової пам'яті та моторної активності, викликані в щурів транзієнтною глобальною церебральною ішемією (ТГЦІ). Використовували тести в Ү-подібному лабіринті та відкритому полі; оцінювали також параметри процесу апоптозу, оксидативного стресу та сигнального шляху оксиду азоту. Розлади просторової пам'яті та моторної активності під впливом греліну (ендогенного ліганда рецепторів гормону росту) зменшувалися. Крім того, в результаті введень греліну знижувалися рівні каспази-3 та індуцибельної NO-синтази в гіпокампі, що були підвищеними після ТГЦІ. Зроблено висновок, що грелін має нейропротективні властивості в умовах ушкодження гіпокампа в наслідок ТГЦІ, впливаючи на процес апоптозу, оксидативний стрес та стан сигнального шляху оксиду азоту. Якщо механізми дії цього агента будуть докладно 3'ясовані, грелін може виявитися перспективним фармакологічним засобом при лікуванні розладів пам'яті, пов'язаних з ТГЦІ.

\section{REFERENCES}

1. A. Peskine, C. Picq, and P. Pradat-Diehl, "Cerebral anoxia and disability," Brain Injury, 18, No. 12, 1243-1254 (2004).

2. Y. D. Cheng, L. Al-Khoury, and J. A. Zivin, "Neuroprotection for ischemic stroke: two decades of success and failure," NeuroRx, 1, No. 1, 36-45 (2004).

3. J. L. Cummings, U. Tomiyasu, S. Read, et al., "Amnesia with hippocampal lesions after cardiopulmonary arrest," Neurology, 34, No. 5, 679-681 (1984).

4. S. Zola-Morgan, L. R. Squire, and D. G. Amaral, "Human amnesia and the medial temporal region: enduring memory impairment following a bilateral lesion limited to field CA1 of the hippocampus," J. Neurosci., 6, No. 10, 2950-2967 (1986).

5. C. K. Petito, E. Feldmann, W. A. Pulsinelli, et al., "Delayed hippocampal damage in humans following cardiorespiratory arrest," Neurology, 37, No. 8, 1281-1286 (1987).

6. W. A. Pulsinelli, J. B. Brierley, and F. Plum, "Temporal profile of neuronal damage in a model of transient forebrain ischemia," Ann. Neurol., 11, No. 5, 491-498 (1982).

7. "Recommendations for standards regarding preclinical neuroprotective and restorative drug development," Stroke, 30, No. 12, 2752-2758 (1999).

8. I. Szabo and A. S. Tarnawski, "Apoptosis in the gastric mucosa: molecular mechanisms, basic and clinical implications," $J$. Physiol. Pharmacol., 51, No. 1, 3-15 (2000).

9. J. Chandra, A. Samali, and S. Orrenius, "Triggering and modulation of apoptosis by oxidative stress," Free Radical Biol. Med., 29, Nos. 3/4, 323-333 (2000).

10. I. Bohm and H. Schild, "Apoptosis: the complex scenario for a silent cell death," Mol. Imag. Biol., 5, No. 1, 2-14 (2003).

11. G. M. Cohen, "Caspases: the executioners of apoptosis," Biochem. J., 326, Part. 1, 1-16 (1997).

12. A. Rami, S. Jansen, I. Giesser, and J. Winckler, "Post-ischemic activation of caspase- 3 in the rat hippocampus: evidence of an axonal and dendritic localization," Neurochem. Int., 43, No. 3, 211-223 (2003).

13. M. Kaste, "Current therapeutic options for brain ischemia," Neurology, 49, No. 5, Suppl. 4, S56-S59 (1997).

14. M. A. Moro, A. Cardenas, O. Hurtado, et al., "Role of nitric oxide after brain ischaemia," Cell Calcium, 36, Nos. 3/4, 265275 (2004).

15. L. J. Ignarro, G. M. Buga, K. S. Wood, et al., "Endotheliumderived relaxing factor produced and released from artery and vein is nitric oxide," Proc. Natl. Acad. Sci. USA, 84, No. 24, 9265-9269 (1987).

16. S. Moncada and J. P. Bolanos, "Nitric oxide, cell bioenergetics and neurodegeneration," J. Neurochem., 97, No. 6, 1676-1689 
(2006).

17. N. Panahian, T. Yoshida, P. L. Huang, et al., "Attenuated hippocampal damage after global cerebral ischemia in mice mutant in neuronal nitric oxide synthase," Neuroscience, $\mathbf{7 2}$, No. 2, 343-354 (1996).

18. C. Iadecola, "Bright and dark sides of nitric oxide in ischemic brain injury," Trends Neurosci., 20, No. 3, 132-139 (1997).

19. A. F. Samdani, T. M. Dawson, and V. L. Dawson, "Nitric oxide synthase in models of focal ischemia," Stroke, 28, No. 6, 12831288 (1997).

20. N. Adachi, B. Lei, M. Soutani, and T. Arai, "Different roles of neuronal and endothelial nitric oxide synthases on ischemic nitric oxide production in gerbil striatum," Neurosci. Lett., 288, No. 2, 151-154 (2000).

21. E. El Eter, A. Al Tuwaijiri, H. Hagar, and M. Arafa, "In vivo and in vitro antioxidant activity of ghrelin: Attenuation of gastric ischemic injury in the rat," J. Gastroenterol. Hepatol., 22, No. 11, 1791-1799 (2007).

22. M. Kojima, H. Hosoda, Y. Date, et al., "Ghrelin is a growthhormone-releasing acylated peptide from stomach," Nature, 402, No. 6762, 656-660 (1999).

23. N. Nagaya, M. Uematsu, M. Kojima, et al., "Chronic administration of ghrelin improves left ventricular dysfunction and attenuates development of cardiac cachexia in rats with heart failure," Circulation, 104, No. 12, 1430-1435 (2001).

24. E. Ghigo, F. Broglio, E. Arvat, et al., "Ghrelin: more than a natural GH secretagogue and/or an orexigenic factor," Clin. Endocrinol., 62, No. 1, 1-17 (2005).

25. M. Kojima and K. Kangawa, "Ghrelin: structure and function," Physiol. Rev., 85, No. 2, 495-522 (2005).

26. J. F. Davis, D. L. Choi, D. J. Clegg, and S. C. Benoit, "Signaling through the ghrelin receptor modulates hippocampal function and meal anticipation in mice," Physiol. Behav., 103, No. 1, 39-43 (2011).

27. J. N. Cuellar and M. Isokawa, "Ghrelin-induced activation of cAMP signal transduction and its negative regulation by endocannabinoids in the hippocampus," Neuropharmacology, 60, No. 6, 842-851 (2011).

28. S. Hwang, M. Moon, S. Kim, et al., "Neuroprotective effect of ghrelin is associated with decreased expression of prostate apoptosis response-4," Endocrinol. J., 56, No. 4, 609-617 (2009).

29. H. Chung, E. Kim, D. H. Lee, et al., "Ghrelin inhibits apoptosis in hypothalamic neuronal cells during oxygen-glucose deprivation," Endocrinology, 148, No. 1, 148-159 (2007).

30. Y. Liu, L. Chen, X. Xu, et al., "Both ischemic preconditioning and ghrelin administration protect hippocampus from ischemia/reperfusion and upregulate uncoupling protein-2," BMC Physiol., 9, 17 (2009).

31. W. A. Pulsinelli and J. B. Brierley, "A new model of bilateral hemispheric ischemia in the unanesthetized rat," Stroke, 10, No. 3, 267-272 (1979).

32. O. Cheng, R. P. Ostrowski, B. Wu, et al., "Cyclooxygenase-2 mediates hyperbaric oxygen preconditioning in the rat model of transient global cerebral ischemia," Stroke, 42, No. 2, 484490 (2011).

33. W. R. Hawley, E. M. Grissom, and G. P. Dohanich, "The relationships between trait anxiety, place recognition memory, and learning strategy," Behav. Brain Res., 216, No. 2, 525-530 (2011).

34. J. Zhao, Y. Zhao, W. Zheng, et al., "Neuroprotective effect of curcumin on transient focal cerebral ischemia in rats," Brain
Res., 1229, 224-232 (2008).

35. G. A. Donnan, M. Fisher, M. Macleod, and S. M. Davis, "Stroke," Lancet, 371, No. 9624, 1612-1623 (2008).

36. W. T. Longstreth Jr. and S. S. Dikmen, "Outcomes after cardiac arrest," Ann. Emerg. Med., 22, No. 1, 64-69 (1993).

37. P. S. Lagali, C. P. Corcoran, and D. J. Picketts, "Hippocampus development and function: role of epigenetic factors and implications for cognitive disease," Clin. Genet., 78, No. 4, 321-333 (2010).

38. S. Diano, S. A. Farr, S. C. Benoit, et al., "Ghrelin controls hippocampal spine synapse density and memory performance," Nat. Neurosci., 9, No. 3, 381-388 (2006).

39. M. Jászberényi, E. Bujdosó, Z. Bagosi, and G. Telegdy, "Mediation of the behavioral, endocrine and thermoregulatory actions of ghrelin," Horm. Behav., 50, No. 2, 266-273 (2006).

40. Y.Liu, P. S. Wang, D. Xie, et al., "Ghrelin reduces injury of hippocampal neurons in a rat model of cerebral ischemia/ reperfusion," Chin. J. Physiol., 49, No. 5, 244-250 (2006).

41. H. A. Awooda, M. F. Lutfi, G. M. Sharara, and A. M. Saeed, "Role of N-Nitro-L-Arginine-Methylester as anti-oxidant in transient cerebral ischemia and reperfusion in rats," Exp. Trans. Stroke Med., 5, No. 1, 1 (2013).

42. M. Yaman, O. Eser, M. Cosar, et al., "Oral administration of avocado soybean unsaponifiables (ASU) reduces ischemic damage in the rat hippocampus," Arch. Med. Res., 38, No. 5, 489-494 (2007).

43. P. H. Chan, "Reactive oxygen radicals in signaling and damage in the ischemic brain," J. Cerebr. Blood Flow Metab., 21, No. 1, 2-14 (2001).

44. K. Zwirska-Korczala, M. Adamczyk-Sowa, P. Sowa, et al., "Role of leptin, ghrelin, angiotensin II and orexins in 3T3 L1 preadipocyte cells proliferation and oxidative metabolism," $J$. Physiol. Pharmacol., 58, Suppl. 1, 53-64 (2007).

45. M. Suematsu, A. Katsuki, Y. Sumida, et al., "Decreased circulating levels of active ghrelin are associated with increased oxidative stress in obese subjects," Eur. J. Endocrinol., 153, No. 3, 403-407 (2005).

46. M. A. Moro, A. Almeida, J. P. Bolaños, and I. Lizasoain, "Mitochondrial respiratory chain and free radical generation in stroke," Free Radical Biol. Med., 39, No. 10, 1291-1304 (2005).

47. S. J. Heales, J. P. Bolaños, V. C. Stewart, et al., "Nitric oxide, mitochondria and neurological disease," Biochim. Biophys. Acta., 1410, No. 2, 215-228 (1999).

48. B. Lei, N. Adachi, T. Nagaro, et al., "Nitric oxide production in the CA1 field of the gerbil hippocampus after transient forebrain ischemia: effects of 7-nitroindazole and NG-nitroL-arginine methyl ester," Stroke, 30, No. 3, 669-677 (1999).

49. J. S. Stamler, "Redox signaling: nitrosylation and related target interactions of nitric oxide," Cell, 78, No. 6, 931-936 (1994).

50. B. Sekhon, C. Sekhon, M. Khan, et al., "N-Acetyl cysteine protects against injury in a rat model of focal cerebral ischemia," Brain Res., 971, No. 1, 1-8 (2003).

51. M. Willmot, C. Gibson, L. Gray, et al., "Nitric oxide synthase inhibitors in experimental ischemic stroke and their effects on infarct size and cerebral blood flow: a systematic review," Free Radical Biol. Med., 39, No. 3, 412-425 (2005).

52. A. Aggarwal, V. Gaur, and A. Kumar, "Nitric oxide mechanism in the protective effect of naringin against post-stroke depression (PSD) in mice," Life Sci., 86, Nos. 25/26, 928-935 (2010).

53. S. Murphy and C. L. Gibson, "Nitric oxide, ischaemia and 
brain inflammation," Biochem. Soc. Trans., 35, Part 5, 11331137 (2007).

54. M. L. Holtz, S. D. Craddock, and L. C. Pettigrew, "Rapid expression of neuronal and inducible nitric oxide synthases during post-ischemic reperfusion in rat brain," Brain Res., 898, No. 1, 49-60 (2001).

55. D. Y. Zhu, Q. Deng, H. H. Yao, et al., "Inducible nitric oxide synthase expression in the ischemic core and penumbra after transient focal cerebral ischemia in mice," Life Sci., 71, No. 17, 1985-1996 (2002).

56. R. Greco, A. S. Mangione, D. Amantea, et al., "IkappaB- alpha expression following transient focal cerebral ischemia is modulated by nitric oxide," Brain Res., 1372, 145-151 (2011).

57. V. P. Carlini, M. F. Perez, E. Salde, et al., "Ghrelin induced memory facilitation implicates nitric oxide synthase activation and decrease in the threshold to promote LTP in hippocampal dentate gyrus," Physiol. Behav., 101, No. 1, 117-123 (2010).

58. T. Brzozowski, P. C. Konturek, S. J. Konturek, et al., "Exogenous and endogenous ghrelin in gastroprotection against stress-induced gastric damage," Regulat. Peptides, 120, Nos. 1/3, 39-51 (2004). 